The White Nuns 
THE MIDDLE AGES SERIES

Ruth Mazo Karras, Series Editor

Edward Peters, Founding Editor

A complete list of books in the series is available from the publisher. 


\section{THE WHITE NUNS}

Cistercian Abbeys for Women in Medieval France

\section{Constance Hoffman Berman}

\section{$\overline{\text { PENN }}$}

UNIVERSITY OF PENNSYLVANIA PRESS

PHIL A DEL P H I A 
Copyright (C) 2018 University of Pennsylvania Press

All rights reserved. Except for brief quotations used for purposes of review or scholarly citation, none of this book may be reproduced in any form by any means without written permission from the publisher.

$$
\begin{gathered}
\text { Published by } \\
\text { University of Pennsylvania Press } \\
\text { Philadelphia, Pennsylvania I9I04-4II2 } \\
\text { www.upenn.edu/pennpress }
\end{gathered}
$$

Printed in the United States of America on acid-free paper I 3579 IO 8642

Library of Congress Cataloging-in-Publication Data ISBN 978-0-8I22-50IO-7 
To my sister Mary

Only she knows how much she has done 
This page intentionally left blank 